\title{
Seasonal dynamics of cyst formation of pelagic strombidiid ciliates in a deep prealpine lake
}

\author{
Helga Müller*, Christine Wünsch \\ Limnological Institute, PO Box 5560, D-78434 Konstanz, Germany
}

\begin{abstract}
Population dynamics of the oligotrich ciliates Limnostrombidium viride and Pelagostrombidium fallax were recorded in prealpine Lake Constance, Germany, from February through November 1997. Simultaneously, their flask-shaped resting cysts were collected in sediment traps. We describe for the first time the resting stages of $L$. viride. Motile stages and cysts of this species were restricted to April/May, with a maximum flux rate of $2 \times 10^{4}$ cysts $\mathrm{m}^{-2} \mathrm{~d}^{-1}$. Pelagostrombidium fallax, a dominant species throughout the year, encysted in March to June and September to November. Maximum flux rates of $1.8 \times 10^{5}$ and $2.1 \times 10^{5}$ cysts $\mathrm{m}^{-2} \mathrm{~d}^{-1}$ were observed in spring and autumn, respectively. Mean flux rates were $4 \times 10^{4}$ cysts $\mathrm{m}^{-2} \mathrm{~d}^{-1}$ in spring and $3 \times 10^{4}$ cysts $\mathrm{m}^{-2} \mathrm{~d}^{-1}$ in autumn. In summer, cyst formation ceased over a period when water temperatures were $>18^{\circ} \mathrm{C}$ close to the lake surface. Encystment of $P$. fallax in spring was significantly negatively correlated with chlorophyll $a$.
\end{abstract}

KEY WORDS: Oligotrichida - Cyst - Limnostrombidium viride - Pelagostrombidium fallax - Survival strategy - Freshwater plankton - Sediment trap

\section{INTRODUCTION}

Distinct flask-shaped cysts, also known as 'papulifères', are typical for ciliates of the orders Oligotrichida and Heterotrichida (Reid \& John 1983) Recent observations indicate that these may play an important role in the life cycle of strombidiid ciliates which live in the pelagic zone of oceans and lakes.

Up to now, resting stages of planktonic strombidiids have been described in 2 marine and 1 freshwater species. Reid (1987) found flask-shaped cysts in sediment traps exposed in the western British Channel, which he assigned to the species Strombidium crassulum (see 'Discussion'). Kim \& Taniguchi $(1995,1997)$ isolated the cysts of Strombidium conicum (identified after excystment) from sediment samples collected in Onagawa Bay on the northeastern Pacific coast of Japan. Müller (1996) observed encystment in laboratory cultures of Pelagostrombidium fallax from pelagic waters of prealpine Lake Constance, Germany. In the present study, we give the first description of the cysts of

•E-mail: helga.mueller@uni-konstanz.de
Limnostrombidium viride, which appeared in a laboratory culture and were found in field samples from the same lake.

The function of cysts in the life cycle of pelagic oligotrich ciliates is unclear. When appearing in late summer and autumn, like those of several marine tintinnids, they may be interpreted as 'overwintering stages' (Reid \& John 1978) enabling survival over a period of low food availability. When ocurring in early spring, as reported for Strombidium crassulum by Reid (1987), they might serve as a defense mechanism against predation. Cyst formation in well-fed laboratory cultures devoid of predators, as observed by Paranjape (1980) in the tintinnid Helicostomella subulata and by Müller (1996) in Pelagostrombidium fallax, points to other, hitherto unknown functions.

The encystment of natural populations of freshwater oligotrich ciliates has not been studied to date. In the present field investigation in Lake Constance, we measured flux rates of the cysts of Limnostrombidium viride and Pelagostrombidium fallax from February through November 1997 using sediment traps. Over the same period, we also recorded the seasonal 
dynamics of the motile populations. Simultaneously, ambient temperature, chlorophyll a (chl a) concentration, and numbers of copepods and cladocerans were determined within an interdisciplinary study program of the Limnological Institute Konstanz. Based on these data, we discuss the present knowledge on encystment as a survival strategy of pelagic strombidiid ciliates.

\section{METHODS}

Lake Constance is a large, deep, mesotrophic, prealpine lake. Our field study was conducted at the routine sampling station of the Limnological Institute Konstanz, which is located at the site of maximum depth $(147 \mathrm{~m})$ of Überlinger See, the fjord-like northwestern part of Lake Constance. At this station, planktonic ciliates have been studied since 1987 (e.g. Müller et al. 1991, Weisse \& Müller 1998).

Strombidiid ciliates were identified according to the descriptions of Krainer (1991), Foissner et al. (1991) and Foissner (1994). Regarding generic names, we followed the nomenclature of Krainer $(1991,1995)$, who placed freshwater strombidids into the newly established genera Limnostrombidium and Pelagostrombidium.

Limnostrombidium viride (Stein, 1867) Krainer, 1995 was isolated from a surface water sample taken on April 22, 1997, and identified by live observation. A small culture, which never contained more than $\sim 30$ individuals, could be maintained for 4 wk with cryptomonads as food. Three flask-shaped cysts, which appeared in this culture, served for comparison with cysts of identical size and shape collected in sediment traps.

Pelagostrombidium fallax (Zacharias, 1896) Krainer, 1991 has been cultivated in our laboratory for several years (Müller \& Geller 1993, Müller 1996). Determination of the species was based on live observation and protargol staining. Cysts in field samples were identified using the description of Müller (1996).

For enumeration of the motile stages of strombidid ciliates, water samples were taken every 2 wk in February and at weekly intervals from March through November 1997 The entire water column from the surface to $20 \mathrm{~m}$ depth was covered by 10 subsequent hauls with a $2 \mathrm{~m}$ long (4 l volume) sampling tube. These samples were combined and cell numbers of Limnostrombidium viride and Pelagostrombidium fallax were determined in $100 \mathrm{ml}$ acid Lugol-fixed subsamples with the Utermöhl technique (cf. Müller 1989, Müller et al. 1991). The detection limit, therefore, was

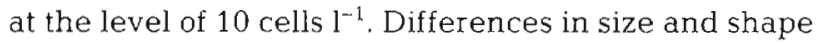
of the fixed specimens served to separate the 2 species. These counts were used to calculate numbers per $\mathrm{m}^{2}$ with the assumption that the entire population was concentrated above $20 \mathrm{~m}$ depth. For distinct periods, we estimated mean daily gross production according to $P=N \times \mu$, where $P$ (cells $\mathrm{m}^{-2} \mathrm{~d}^{-1}$ ) is the production rate, $N$ (cells $\mathrm{m}^{-2}$ ) is the mean abundance within this period, and $\mu\left(\mathrm{d}^{-1}\right)$ is the growth rate, using $\mu$ values of $0.693,0.231$ and $0.138 \mathrm{~d}^{-1}$, which are equivalent to generation times of 24,72 and 120 h (see 'Discussion').

We used cylindrical sediment traps which corresponded to the recommendations of Bloesch \& Burns (1980). They were made of transparent plexi-glass, had a height of $100 \mathrm{~cm}$ and an inner diameter of $10 \mathrm{~cm}$. For details of the mooring system and retrieval technique see Gries \& Güde (1999). Four replicates of these traps were exposed at $35 \mathrm{~m}$ depth at the sampling station. With consecutive exposures we covered the entire period from January 31 to November 27, 1997. During trap exchange, $\sim 2 \mathrm{~h}$ elapsed between trap retrieval and lowering of new traps. We started with 2 relatively long exposures from January 31 to March 3 and March 3 to April 3. Between April 3 and November 10, the traps were exchanged every 3 to $4 \mathrm{~d}$ (occasionally $7 \mathrm{~d}$ ). The final exposure lasted from November 10 to 27 .

Immediately after trap retrieval the collected material was sieved through 200 and $30 \mu \mathrm{m}$ mesh. The 30 to $200 \mu \mathrm{m}$ fraction of 2 traps was fixed with acid Lugol's solution for cyst enumeration and sizing. The rest of the material was stored at $4^{\circ} \mathrm{C}$ in the dark and was used for live observation. Some of these samples were fixed with $2 \%$ glutaraldehyde and critical point dried for examination by scanning electron microscopy (SEM).

The Lugol-fixed samples were concentrated by centrifugation and resuspended in a defined water volume. Depending on the amount of sedimented material, we used the contents of 1 or 2 traps to prepare concentrated samples of 10 or $20 \mathrm{ml}$. From these, $1 \mathrm{ml}$ subsamples were taken and filled into SedgewickRafter chambers. Using phase-contrast microscopy, 2 or 3 entire chambers were scanned for cysts at 100 -fold magnification. Numbers of cysts per chamber ranged from 0 to $\sim 600$. The examined material corresponded to $10-40 \%$ of the contents of one trap. Flux rates (cysts $\mathrm{m}^{-2} \mathrm{~d}^{-1}$ ) were calculated from these counts, the total area of the trap $\left(78.5 \mathrm{~cm}^{2}\right)$ and the exposure time.

Cyst dimensions were determined at 200 -fold magnification with a calibrated eyepiece micrometer. Data from different samples were compared by the MannWhitney Rank Sum Test, using the statistical software SigmaStat (Jandel Scientific, CA, USA).

Water temperature, chl a concentration and crustacean abundance were determined with standard methods by our colleagues at the Limnological Institute Konstanz in parallel to the present investigation. Generally, these parameters and ciliate cell concentra- 
tions were measured every Tuesday, whereas sediment traps were exchanged every Monday and Thursday. To study the impact of environmental parameters on cyst production, we related mean flux rates as recorded from Monday to Monday to abundances of motile strombidids as measured on Tuesdays of the same week, with the assumption that the cysts would need less than $1 \mathrm{wk}$ to sediment from the epilimnion to a depth of $35 \mathrm{~m}$, where the traps were exposed (see 'Discussion'). Relationships between environmental parameters and cyst production were tested by multiple regression analysis using the statistical software SigmaStat (Jandel Scientific, CA, USA).

\section{RESULTS}

\section{Cyst morphology and identification}

Two types of strombidiid cysts which differed in size and surface structure were found in the sediment traps (Figs. 1-10, Table 1). Both had a characteristic shape resembling a small flask with the aperture closed by a hyaline plug (the 'papulla'), indicating they were 'papulifères' according to the definition of Reid \& John (1983). Light microscopy revealed a colourless transparent cyst wall enclosing cytoplasm of granular structure, which stained very dark with acid Lugol's solution (Figs. 1-5). The surface of the small cysts was ornamented with spines, which were hardly visible with light microscopy, but prominent on SEM micrographs (Figs. $4 \& 9$ ). The large cysts were covered with ridges instead of spines (Figs. 6-8 \& 10). These differences in surface properties were also obvious at low magnification, since a large number of detrital particles such as diatom frustules were adhering to the small, but not to the large flasks. As a consequence, the small cysts, though much more numerous, were extremely difficult to detect in unfixed field samples and in SEM preparations. They were easily recognized only after Lugol's fixation, which facilitated the counting procedure (Fig. 1).
By their size and surface structure the small cysts were identified as resting stages of Pelagostrombidium fallax, which have been described by Müller (1996). Field cysts collected in spring had nearly the same dimensions as those reported by Müller (1996) from laboratory cultures, whereas the cysts found in an autumn field sample were slightly, but significantly, smaller (Table 1).

The large cysts have not been observed previously. Their maximum production occurred in the first weeks of May. At the same time, similar cysts (Fig. 3, Table 1) appeared in a culture of Limnostrombidium viride which had been isolated on April 22 at the sampling location. We therefore conclude that the large cysts described above were the resting stages of $L$. viride.

In both species, the papulla seems to be rather fragile. Several cysts with a damaged papulla were found in field samples (Figs. 8-10). Similar specimens have been observed in laboratory cultures of Pelagostrombidium fallax (Müller unpubl.), Light microscopy revealed that these cysts had the same cytoplasm contents as the cysts with an intact papulla, indicating that they were not remains of excysted cells.

One flask-shaped cyst of unclear identity was found in a field sample from May 5 (Fig. 11). It had the size and shape of a Pelagostrombidium fallax cyst, a smooth surface without spines and a papulla with an open lid. Several cracks were visible in the cyst wall. This specimen might be interpreted as an excysted stage of a $P$. fallax cyst, with the assumption that the spines typical for this species had decayed.

\section{Seasonal dynamics of cyst production}

Motile stages of Limnostrombidium viride were only observed from April 2 through May 25 (Fig. 12d). Mean cell concentrations in the 0 to $20 \mathrm{~m}$ depth interval were low, ranging from 10 to 120 cells $\mathrm{l}^{-1}$, while over the rest of the year abundances were below detection limits. Cysts of $L$. viride were found in the sediment traps from April 21 through June 2 (Fig. 12e).

Table 1. Limnostrombidium viride and Pelagostrombidium fallax. Dimensions of cysts from laboratory cultures and field samples. We measured live cysts from laboratory cultures and acid Lugol-fixed field cysts. The Mann-Whitney Rank Sum Test revealed significant differences in both length and width of $P$. fallax cysts from spring and autumn field samples $(p<0.001)$

\begin{tabular}{|llccc|}
\hline Species & Origin of sample & Length $(\mu \mathrm{m} \pm \mathrm{SD})$ & Width $(\mu \mathrm{m} \pm \mathrm{SD})$ & $\mathrm{n}$ \\
\hline L. viride & Laboratory culture (this study) & $107 \pm 6$ & $79 \pm 3$ & 2 \\
& Sediment trap 28 Apr to 5 May 1997 & $96 \pm 5$ & $70 \pm 3$ & 30 \\
& & & $46 \pm 1$ & 30 \\
P. fallax & Laboratory culture (Müller 1996) & $67 \pm 3$ & $41 \pm 1$ & 30 \\
& Sediment trap 28 Apr to 5 May 1997 & $59 \pm 2$ & $36 \pm 1$ & 30 \\
\hline
\end{tabular}


At the beginning of May, shortly after maximum development of the motile population, the highest flux rate of $2.2 \times 10^{4}$ cysts $\mathrm{m}^{-2} \mathrm{~d}^{-1}$ was recorded. Altogether, the L.viride population produced $3 \times 10^{5}$ cysts $\mathrm{m}^{-2}$ (Table 2).
Motile stages of Pelagostrombidium fallax were present from February through November, with maximum development in spring, intermediate numbers in summer and low abundances in autumn (Fig. 12b). Mean cell concentrations in the 0 to $20 \mathrm{~m}$ depth interval
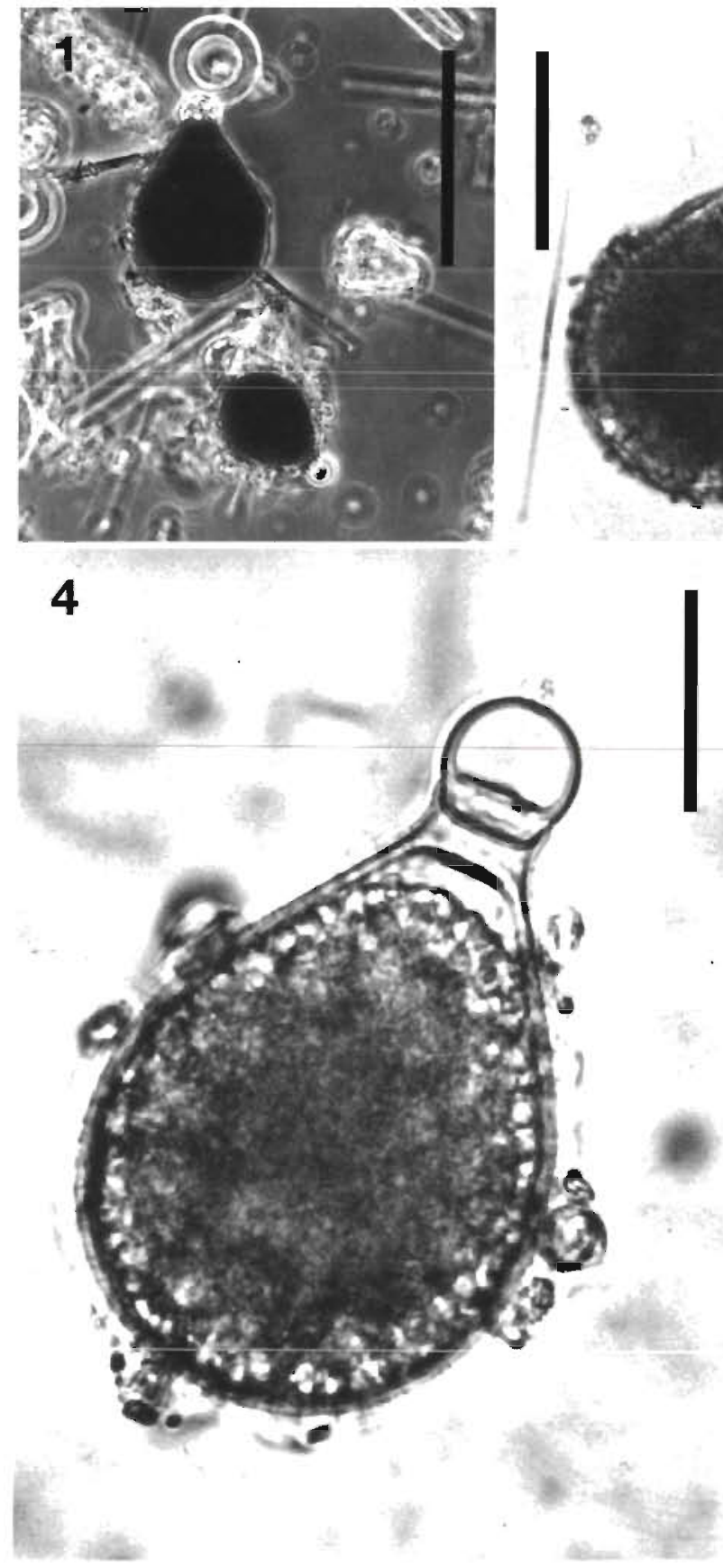
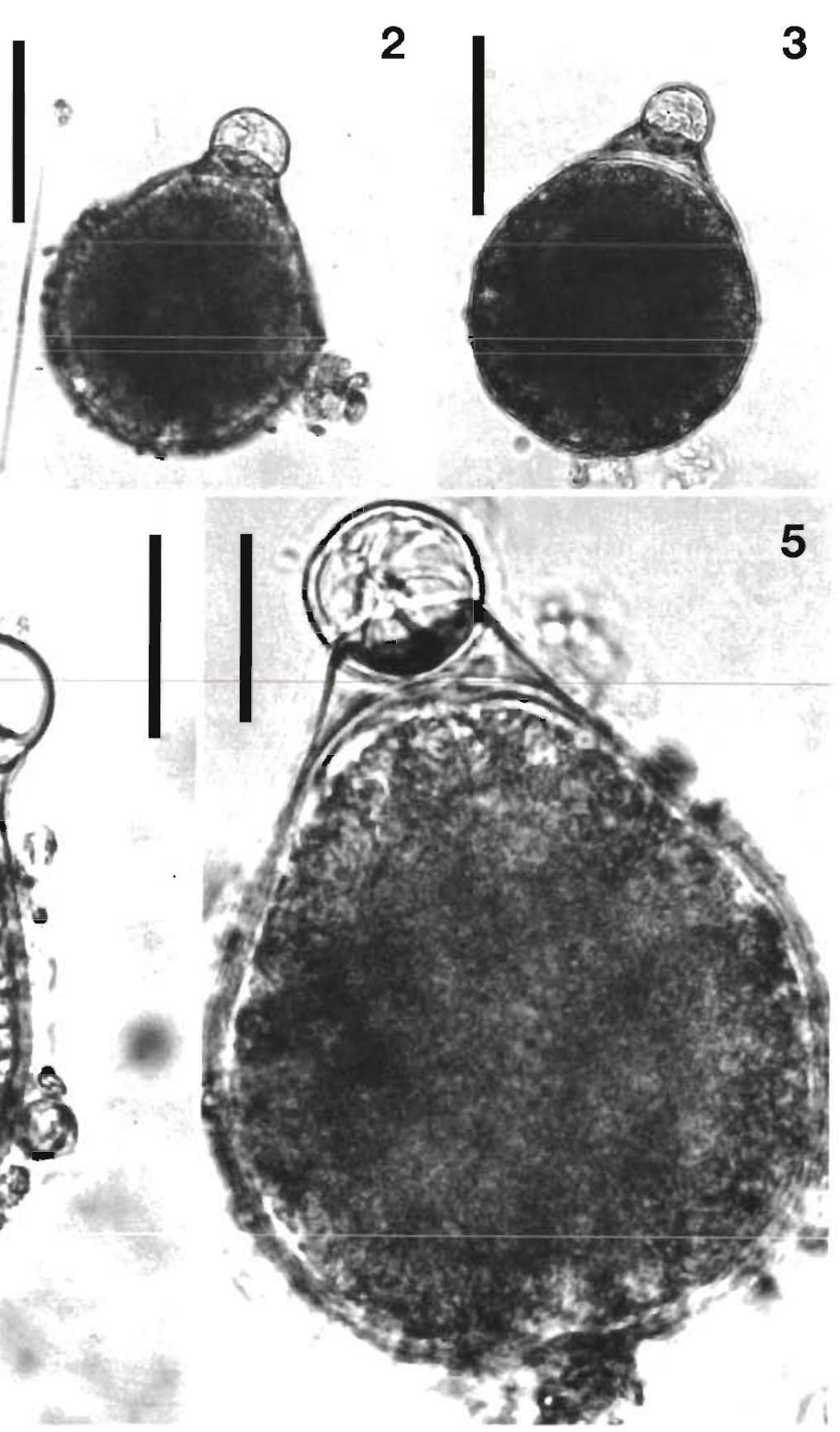

Figs. 1 to 5. Photomicrographs of strombidiid cysts. Fig. 1. Lugol-fixed sediment trap material from May 5, with 1 cyst each of Limnostrombidium viride (large, with clean surface) and Pelagostrombidium fallax (small, covered with detritus). Figs. 2 \& 5 . Live $L$. viride cysts from sediment trap retrieved on May 5. Fig. 3. Live L. viride cyst from laboratory culture. Fig. 4. Live $P$. fallax cyst from sediment trap retrieved on April 10. Scale bars: Fig. 1, $100 \mu \mathrm{m}$; Figs. 2 \& 3, $50 \mu \mathrm{m}$; Figs. 4 \& 5, $20 \mu \mathrm{m}$ 

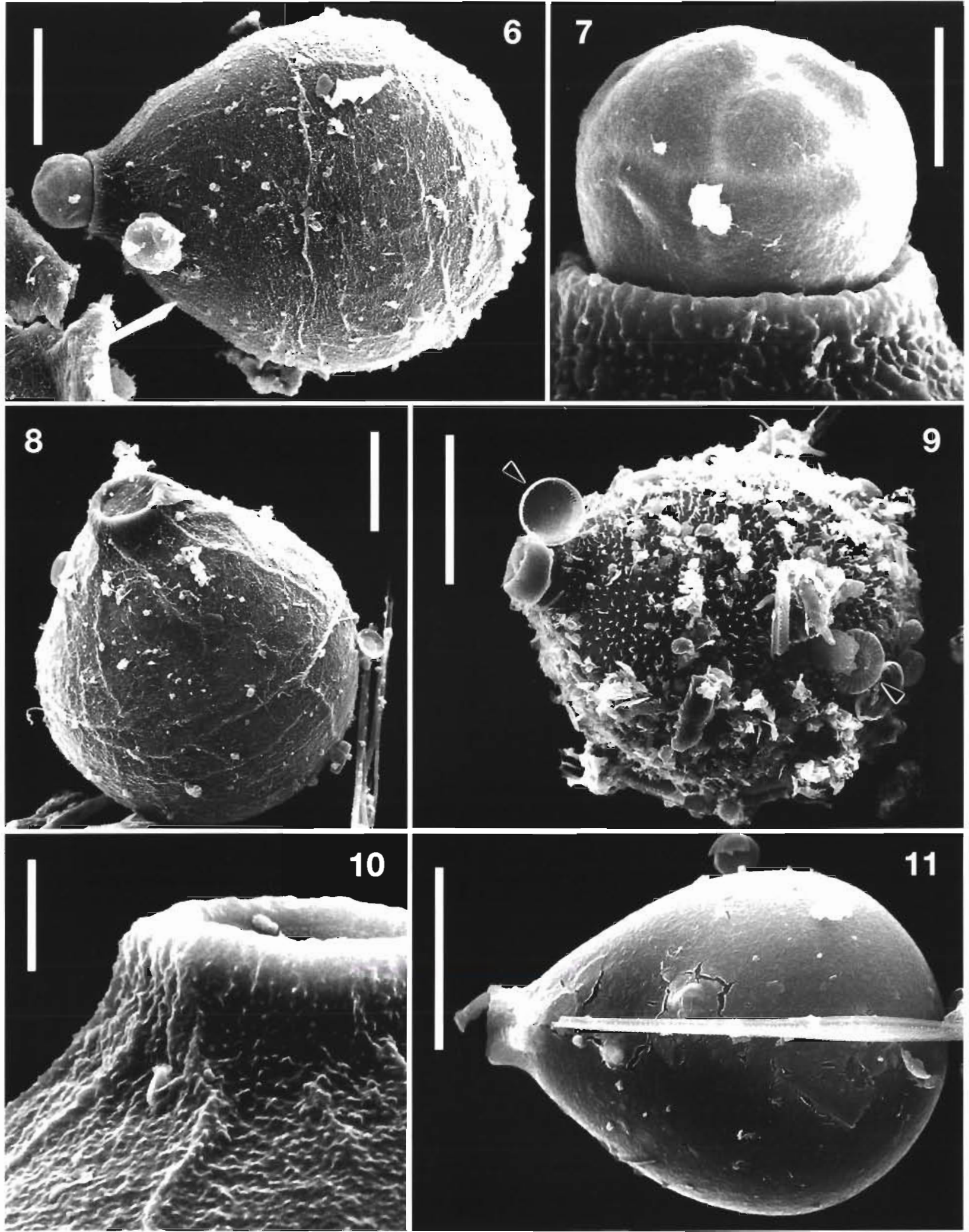

Figs. 6 to 11. Scanning electron micrographs of strombidiid cysts collected by sediment traps between April 28 and May 12 . Fig. 6 . Cyst of Limnostrombidium viride. Fig. 7. Papulla of the same specimen. Fig. 8. L. viride cyst with damaged papulla. Fig. 9. Cyst of Pelagostrombidium fallax with damaged papulla. The cyst surface is ornamented with spines and covered with detritus. Arrowheads point to 2 frustules of centric diatoms. Fig. 10. Detail of $L$. viride cyst (with damaged papulla) showing ridges on the cyst surface. Fig. 11. Cyst of unclear identity, presumably an excysted stage of a $P$. fallax cyst (see text). The straight object is the frustule of a pennate diatom. Scale bars: Figs. $6,8,9 \& 11,20 \mu \mathrm{m}_{i}$ Figs. $7 \& 10,5 \mu \mathrm{m}$ 

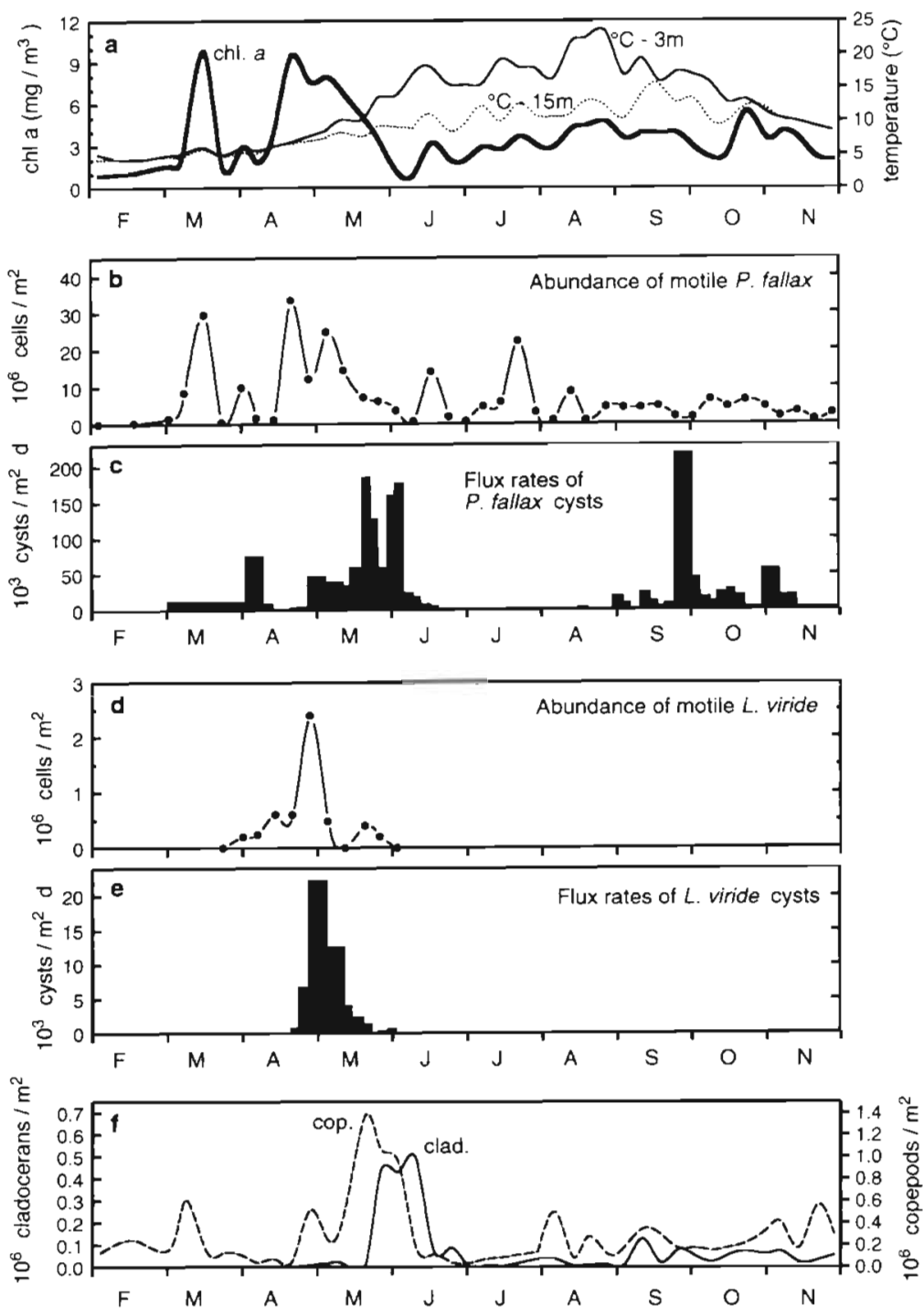

Fig. 12. Field data from Lake Constance, 1997. (a) Bold straight line: chl a concentrations, mean values in the 0 to $20 \mathrm{~m}$ depth interval. Thin straight line: water temperature at $3 \mathrm{~m}$ depth. Stippled line: water temperature at $15 \mathrm{~m}$ depth. (b) Cell counts of motile Pelagostrombidium fallax, integrated over the 0 to $20 \mathrm{~m}$ depth interval. (c) Flux rates of $P$. fallax cysts, averaged over trap exposure periods. (d) Cell counts of motile Limnostrombidium viride, integrated over the 0 to $20 \mathrm{~m}$ depth interval. (e) Flux rates of $L$. viride cysts, averaged over trap exposure periods. (f) Individual numbers of cladocerans (straight line) and copepods (broken line)
No strombidiid cysts were observed during the first trap exposure in February, whereas the traps exposed in March collected a considerable number of Pelagostrombidium fallax cysts. Since these traps were in the lake for an entire month, we do not know exactly when this population started to form cysts. The mean flux rate between March 3 and April 3 was $~ 12 \times 10^{3}$ cysts $\mathrm{m}^{-2} \mathrm{~d}^{-1}$ (Fig. 12c); however, flux rates were likely not constant over this period. Considering the development of the motile population in March (Fig. 12b), we suspect that most of these cysts were formed during the second half of the trap exposure.

\section{Cyst production in relation to total population production}

We roughly estimated the mean daily gross production rates of Limnostrombidium viride over the entire period of its appearance, and of Pelagostrombidium fallax for the seasonal periods mentioned above, with the assumption that mean generation times were in the range between 24 and $120 \mathrm{~h}$ (see 'Discussion'). These rates served for comparison with measured values of mean daily cyst production. It is evident from the results shown in Table 2 that only a small fraction of the total population production resulted in cyst formation. For $L$. viride and $P$. fallax in autumn this fraction was $<6 \%$, for $P$. fallax in spring it was $<3 \%$. While these are average values over periods of 2 to $3 \mathrm{mo}$, the ratio of cyst production:total production could be higher for a shorter time interval. For the autumn period of maximum encystment of $P$. fallax (September 22 to 29 ) the same calculation resulted in a ratio of cyst production: total production between 16 and $80 \%$. ranged from 10 to 1700 cells $1^{-1}$. Cyst formation occurred mainly in spring and autumn (Fig. 12c), with peaks of $1.8 \times 10^{5}$ and $2.1 \times 10^{5}$ cysts $\mathrm{m}^{-2} \mathrm{~d}^{-1}$ in May and September, respectively. Summarized over the study period, $7 \times 10^{6}$ cysts $\mathrm{m}^{-2}$ were deposited. Three seasonal periods can be distinguished: $59 \%$ of these cysts were produced between March 3 and June 16, $1 \%$ between June 16 and August 25 and $40 \%$ between August 25 and November 27 (cf. Table 2).

\section{Encystment in relation to environmental parameters}

\section{Temperature}

From March through November, water temperatures ranged from 4.7 to $23.4^{\circ} \mathrm{C}$ in $3 \mathrm{~m}$ depth, and from 4.6 to $15.5^{\circ} \mathrm{C}$ in $15 \mathrm{~m}$ depth (Fig. 12a).

During the short period of high flux rates of Limnostrombidium viride cysts, temperatures in both depths 
were between 7 and $10^{\circ} \mathrm{C}$. We have no evidence that cyst production of this species was controlled by temperature.

Flux rates of Pelagostrombidium fallax cysts declined in the first half of June, when temperatures in $3 \mathrm{~m}$ depth increased from 13.7 to $18.1^{\circ} \mathrm{C}$. In autumn, encystment started when temperatures close to the lake surface dropped from $23.4^{\circ} \mathrm{C}$ (August 26) to $16.9^{\circ} \mathrm{C}$ (September 2). These data suggest that high water temperatures might impede encystment of $P$. fallax.

\section{Chlorophyll a}

Mean chl a concentrations in the 0 to $20 \mathrm{~m}$ depth interval ranged from 1 to $10 \mathrm{mg} \mathrm{m}^{-3}$, with 2 spring maxima in March and April (Fig. 12a). Highest concentrations of Limnostrombidium viride were recorded shortly after the second chl a peak. Cyst formation coincided with the decline of the motile population, which occurred when chl a concentrations were still high. Our data, therefore, do not point to a close relationship between encystment of $L$. viride and chl a (Fig. 12a,d,e).

Cell numbers of Pelagostrombidium fallax in spring (April 3 through June 16) were positively correlated with chl a concentrations (Fig. 13a; $p<0.001$ ). For the same period, we tested the impact of chl a concentration on encystment of $P$. fallax. We determined the ratio of cyst production : total production separately for each week by the protocol shown in Table 2, but assuming a constant generation time of $72 \mathrm{~h}$ (see 'Discussion'). The resulting values of '\% encystment' were negatively correlated with 'chl $a^{\prime}$ (Fig. 13b; $p<0.01$ ). This suggests that decreasing availability of algal food might enhance encystment of $P$. fallax.

Data from February and March were excluded from these calculations, since no weekly measurements of cyst production were available. For the summer and autumn periods, no significant relationships of ciliate abundance and encystment with chl a could be detected.

\section{Crustacean predators}

Seas̄onal changes in numbers of copepods and cladocerans are depicted in Fig. 12f. The motile population of Limnostrombidium viride declined at the end of April, shortly after a small peak of copepods had developed, and entirely disappeared during the clearwater phase (end of May to mid-June), when cladocerans and copepods had reached maximum abundance. Resting stages were first found when numbers of crustaceans were still low; maximum flux rates were recorded together with the small copepod peak in April. High flux rates of Pelagostrombidium fallax cysts in spring were observed simultaneously with maximum development of crustaceans. The autumn peak of $P$. fallax encystment obviously was not related to abundance of crustacean predators.

Table 2. Limnostrombidium viride and Pelagostrombidium fallax. Production estimates of the populations (assuming generation times between 24 and $120 \mathrm{~h}$ ) versus measurements of cyst production during different seasonal periods (see text)

\begin{tabular}{|c|c|c|c|c|c|c|}
\hline Species & Time interval & $\begin{array}{l}\text { Mean number } \\
\text { of motile ciliates } \\
\left(10^{3} \text { cells } \mathrm{m}^{-2}\right)\end{array}$ & $\begin{array}{c}\text { Mean daily } \\
\text { production } \\
\left(10^{3} \text { cells } \mathrm{m}^{-2} \mathrm{~d}^{-1}\right)\end{array}$ & $\begin{array}{l}\text { Total number of } \\
\text { sedimented cysts } \\
\left(10^{3} \text { cysts } \mathrm{m}^{-2}\right)\end{array}$ & $\begin{array}{c}\text { Mean daily } \\
\text { cyst production } \\
\left(10^{3} \text { cysts } \mathrm{m}^{-2} \mathrm{~d}^{-1}\right)\end{array}$ & $\begin{array}{c}\text { Cyst production/ } \\
\text { total production } \\
(\%)\end{array}$ \\
\hline L. viride & 3 Apr to 2 Jun & 570 & $80-400$ & 304 & 5.1 & $1-6$ \\
\hline P. fallax & $\begin{array}{l}3 \mathrm{Mar} \text { to } 16 \mathrm{Jun} \\
16 \mathrm{Jun} \text { to } 25 \mathrm{Aug} \\
25 \mathrm{Aug} \text { to } 27 \mathrm{Nov}\end{array}$ & $\begin{array}{r}10430 \\
6480 \\
3770\end{array}$ & $\begin{array}{r}1440-7200 \\
900-4500 \\
520-2600\end{array}$ & $\begin{array}{r}4310 \\
56 \\
2895\end{array}$ & $\begin{array}{l}41 \\
0.81 \\
31\end{array}$ & $\begin{array}{l}0.6-3 \\
<0.1 \\
1-6\end{array}$ \\
\hline
\end{tabular}


Multiple regression analysis

Multiple regression analysis was used to investigate the combined impact of temperature, food availability and predator abundance on encystment in spring (April 3 through June 16). Preliminary tests had revealed multicollinearity between the variables 'temperature' and 'cladoceran abundance'. Therefore, to avoid combination of these 2 parameters, multiple linear regression equations with ' $\%$ encystment' as the dependent variable were calculated for 2 different models: either with 'chl $a$ ', 'temperature' and 'crustacean abundance' or with 'chl $a$ ', 'copepod abundance' and 'cladoceran abundance' as the independent variables. In both models, the regression coefficients of 'chl $a$ ' were significant at the $5 \%$ level, whereas other variables did not significantly add to the ability of the equations to predict '\% encystment'. Elimination of these non-significant variables by the backward stepwise procedure reduced both models to the linear relationship between '\% encystment' and 'chl a' shown above (Fig. 13b).

\section{DISCUSSION}

\section{Taxonomic identification}

Despite the existence of detailed descriptions in the literature, there are open questions with respect to the identification of freshwater strombidiid ciliates. Krainer $(1991,1995)$ argued that descriptions of Strombidium viride in the older literature refer to a conglomeration of several species. However, his newly established species Strombidium pelagicum (later changed to Limnostrombidium pelagoviride) is considered as a junior synonym of $S$. viride (now $L$. viride) by Foissner et al. (1991) and Foissner (1994). We were not able to study the small differences which might separate these 2 species (or forms). Following the description of $L$. viride by Foissner et al. (1991) we identified our ciliates by live observation with special attention to the following characters: large size (up to $100 \mu \mathrm{m}$ in length), ciliary girdle near mid-body, tube-like neoformation organelle and existence of a ventral kinety.

According to Krainer (1991) and Foissner (1994) the species Pelagostrombidium mirabile (Penard, 1916) Krainer, 1991 and P. fallax (Zacharias, 1896) Krainer, 1991 are distinguished by numbers of buccal membranelles ( $P$. mirabile: 12 to 15; $P$. fallax: 19 to 22), shape of polysaccharide plates ( $P$. mirabile: square $P$. fallax: polygonal) and colour ( $P$. mirabile: greenishgrey to orange-yellow; $P$. fallax: reddish-brown). However, recent observations of Foissner (pers. comm.) revealed that numbers of buccal membranelles in these taxa may be rather variable, with the conse- quence that separation of both species by this character is problematic. We examined the population from Lake Constance by live observation and protargol staining. Distinguishing features of the genus were the supraequatorially located ciliary girdle and the potatoshaped neoformation organelle. A long row of buccal membranelles (>16) extending at least half cell length internally and polygonal polysaccharide plates pointed to the species $P$. fallax. Colour was a less reliable taxonomic character. Specimens collected from the lake appeared brown or reddish-brown, whereas cultured specimens adopted a green colour similar to that of their cryptomonad food. Additional taxonomic work is needed to decide whether the separation of both species is justified, a problem already discussed by Kahl (1932).

\section{Morphology of strombidiid cysts}

Up to now, resting stages of 4 planktonic strombidiid ciliates have been described, namely Strombidium conicum (Kim \& Taniguchi 1995), Pelagostrombidum fallax (Müller 1996), Limnostrombidium viride (this study) and a ciliate provisionally identified as Strombidium crassulum. Unfortunately, identification of the latter species by Reid (1987) is doubtful, since it is documented by illustrations which obviously show a strobilidiid ciliate. Notwithstanding, we will refer to this ciliate as $S$. crassulum in the following text. The cysts of these 4 species are similar in shape: flasks with an aperture through which the excysting ciliate will emerge (Kim \& Taniguchi 1995), which is closed by a hyaline plug. Cyst size and surface structure differ between species. According to the authors cited above, cysts of $S$. crassulum and $P$. fallax are covered with spines and those of $L$. viride with ridges, while the surface of $S$. conicum cysts shows a network of fine fibers. Notably, cysts of this latter species were isolated from marine sediments, where they had been deposited for an unknown period, during which their surface structure could have been changed by mechanical forces.

Cysts of Pelagostrombidum fallax from the spring and autumn period were strikingly similar, except for a small difference in size. which may be explained by the better nutritional state of the motile population during the phytoplankton spring bloom.

A strombidid ciliate from a different environment is well-known to form cysts: Strombidium oculatum living in tide pools alternates between an encysted and excysted stage with a circatidal rhythm (Fauré-Fremiet 1948, Jonsson 1994). While the abovementioned planktonic species are assumed to remain encysted for several weeks or months, only $\sim 18$ h elapse between en- and excystment of $S$. oculatum. These temporary 
cysts are more or less spherical in shape, but also possess a distinct aperture closed by a 'frothy plug' (Fauré-Fremiet 1948),

\section{Determination of flux rates}

Problems relating to the sediment trap technique have been discussed in detail by Bloesch \& Burns (1980). According to these authors, over- or underestimation of downward settling fluxes will be caused by (1) inappropriate trap design, (2) resuspension of bottom deposits and (3) decomposition of collected material during trap exposure. Our trap design, simple cylinders with a height: diameter ratio of 10 , followed their recommendations. Overestimation due to resuspension of bottom deposits was unlikely, since our traps were exposed at a large distance from the lake bottom. The third problem, especially in the form of cyst consumption by predatory protozoans and metazoans, could have been of some significance in our study. The effect can be minimized by short trap exposure times, and thus presumably was negligible in our samples from April through September. Underestimation of flux rates due to predation might have occurred mainly during the long exposure periods in February, March and November.

Our data emphasize the quantitative importance of downward settling fluxes of strombidiid cysts. Notably, cyst fluxes of Pelagostrombidium fallax in our study on average were higher by an order of magnitude than those reported by Reid (1987) for Strombidium crassulum.

\section{Problems in relating flux rates to numbers of motile ciliates}

Strombidiid ciliates tend to live close to the lake surface. As reported by Müller et al. (1991) for Lake Constance, their cell concentrations in the 0 to $8 \mathrm{~m}$ depth interval generally are 3 -fold higher than in the 8 to $20 \mathrm{~m}$ depth interval. Virtually no strombidiids are found below $20 \mathrm{~m}$ depth (Müller unpubl.). Consequently, we believe that the strombidiid cysts collected in our traps were formed within the 0 to $20 \mathrm{~m}$ depth interval.

In the present study, we measured strombidiid abundance once a week in the 0 to $20 \mathrm{~m}$ depth interval, whereas cysts were collected continuously at $35 \mathrm{~m}$ depth. To relate these data sets, we had to consider 2 problems: (1) estimation of the time delay between formation and collection of cysts; and (2) conversion of abundance data to production rates, to allow comparison with rates of cyst production.

\section{Sinking velocity of cysts}

According to Stokes' law, a sphere with a diameter of $50 \mu \mathrm{m}$ and a density of $1.2 \mathrm{~g} \mathrm{ml}^{-1}$ (as assumed for diatoms by Sommer 1984) will sink with a speed of $15 \mathrm{~m} \mathrm{~d}^{-1}$ at $5^{\circ} \mathrm{C}$ and of $23.5 \mathrm{~m} \mathrm{~d}^{-1}$ at $20^{\circ} \mathrm{C}$. Strombidiid cysts, however, are not spheres, and we do not know their exact density. We observed sinking of live Pelagostrombidium fallax cysts under a dissecting microscope at $8^{\circ} \mathrm{C}$ over a distance of $4 \mathrm{~cm}$ and recorded a speed of $\sim 1 \mathrm{~cm} \mathrm{~min}^{-1}\left(-14.4 \mathrm{~m} \mathrm{~d}^{-1}\right)$. Since these simple measurements yielded a value similar to that of the model calculations, they support our assumption that cysts produced between 0 and $20 \mathrm{~m}$ depth will reach the $35 \mathrm{~m}$ level within 1 to $3 \mathrm{~d}$. The effect of turbulence on settling of particles $<500 \mu \mathrm{m}$ is low, as explained in detail by Bloesch \& Burns (1980).

\section{Production rates}

Estimates of ciliate production in Table 2 were made with the assumption that mean growth rates of strombidids were in the range from 0.14 to $0.69 \mathrm{~d}^{-1}$. For comparison: Müller \& Geller (1993) measured maximum growth rates of Pelagostrombidium fallax of 0.21 and $0.76 \mathrm{~d}^{-1}$ at 9 and $18.5^{\circ} \mathrm{C}$, respectively. These rather crude calculations only served to estimate the order of magnitude of population production; nevertheless, they demonstrate that cyst formation was only a small fraction of total population production. To investigate the relationship between encystment of $P$. fallax and chl a concentrations in spring (Fig. 13b), we calculated mean production rates separately for $10 \mathrm{wk}$. For this we used a constant growth rate of $0.23 \mathrm{~d}^{-1}$, which admittedly is a severe simplification. In reality, growth may be faster at high and slower at low algal abundance, such that values of '\% encystment' would be lower at high and higher at low chl a concentrations compared to those shown in Fig. 13b. The negative relationship between '\% encystment' and 'chl $a$ ' as illustrated in Fig. 13b then would be even more obvious, due to a steeper regression line.

\section{Impact of environmental parameters on cyst formation}

\section{Chlorophyll a}

The phytoplankton spring bloom in Lake Constance is mainly composed of small unicellular algae which can be ingested by protozoa. Chl $a$, therefore, is a good indicator of food availability for algivorous ciliates in this season (Weisse et al. 1990). Our observation of a 
negative relationship between chl a concentration and encystment of Pelagostrombidium fallax agrees well with experimental data of Müller (1996). In her P. fallax cultures, cyst formation occurred at high and low food levels, but was enhanced during phases of decreasing prey concentrations, which is exactly what we observed during the phytoplankton spring bloom (Fig. 12a,b,c). Later in the year, chl a data are less representative of food concentration, due to a higher proportion of large, unedible algae. It is not surprising, therefore, that we found no significant relationships of chl a with $P$. fallax abundance and encystment in summer and autumn.

\section{Temperature}

Due to their depth distribution (see above) strombidiid ciliates are likely to be affected by the pronounded temperature changes close to the lake surface. Our data (Fig. 12) suggest that water temperatures $>18^{\circ} \mathrm{C}$ could have impeded cyst production of Pelagostrombidium fallax during the summer months. Unfortunately, we were not able to test this hypothesis experimentally, since encysting $P$. fallax cultures did not even survive a transfer from 9 to $15^{\circ} \mathrm{C}$ (Müller unpubl.). Furthermore, it must be considered that part of the P. fallax population in Lake Constance is also found in deeper waters at lower temperatures. Future work is needed for a better understanding of the relationship between temperature and encystment of this strombidid ciliate.

\section{Crustacean predators}

Suppression of ciliate populations due to metazoan predation is well known in the literature, as reviewed by Jack \& Gilbert (1997).

Our records of strombidiid encystment in early spring are in agreement with observations of Reid (1987), who found cysts of Strombidium crassulum in the western British Channel in April, at the start of the growing season. He argued that at this time of the year encystment might serve as a protection against copepod predation rather than for survival of starvation periods

In our study, Limnostrombidium viride formed cysts at the end of April, when food concentrations were still high. Thus, encystment of this species could have been a response to increasing predation pressure by copepods, though we do not have experimental support for this hypothesis. For Pelagostrombidium fallax, statistical analysis of data collected in spring did not reveal a significant relationship between cyst production and numbers of crustaceans. Nevertheless, we cannot exclude that such a relationship could have been detected with a more refined method to estimate values of '\% encystment'. In autumn, cyst formation of $P$. fallax obviously was not connected to crustacean abundance.

\section{Conclusions and open questions}

The present study is the first record of cyst formation in field populations of freshwater strombidid ciliates. Cyst fluxes of Limnostrombidium viride and Pelagostrombidium fallax in Lake Constance were observed in considerable quantities and with pronounced seasonal dynamics. To some extent, they were related to environmental parameters. Beyond these observations, a large number of questions remain.

Is encystment of these ciliates triggered solely by environmental cues? We have been unable to reliably induce cyst formation in cultures of Pelagostrombidium fallax by varying food concentrations, temperature, light conditions and presence/absence of crustacean predators (Müller 1996, unpubl. data). Is encystment an integral part of the strombidiid life cycle? We occasionally observed conjugation in our cyst forming $P$. fallax cultures, but we did not study this phenomenon in detail.

Which factors control excystment? How long is the period of dormancy? Will cysts formed in early spring excyst after the clear-water phase or will they rest in the sediment for an entire year or longer? Does excystment occur at the lake bottom or only after resuspension of sediments to the lake surface? Kim \& Taniguchi (1995) could trigger excystment of Strombidium conicum by changes in light and temperature. In similar experiments with Pelagostrombidium fallax, we observed excystment just once, and we do not know which factors caused excystment in this case (Müller unpubl.). Kim \& Taniguchi (1997) found a pronounced seasonality of the excystment pattern of $S$. conicum, which was significantly correlated with ambient temperature. These $S$. conicum cysts were collected from sediments with a considerable seasonal temperature variation between 8 and $18^{\circ} \mathrm{C}$. At our sampling location, temperatures at the lake bottom (in $140 \mathrm{~m}$ depth) are close to $4^{\circ} \mathrm{C}$ throughout the year. If $P$. fallax would excyst at this depth, only chemical cues or spontaneous excystment could be considered. The excysted ciliates then would have to swim a long way up to the lake surface. In contrast, if excystment would occur only after resuspension to the epilimnion, it should be restricted to the unstratified winter and early spring period.

Finally, what is the function of strombidid resting stages? While our field data are in agreement with ear- 
lier explanations, namely escape from predation and survival of starvation periods (see 'Introduction'), they do not furnish strict evidence for these hypotheses. Detailed experimental work is needed to elucidate the survival strategies of planktonic oligotrich ciliates.

Acknowledgements. This study was supported by the Deutsche Forschungsgemeinschaft within the Special Collaborative Program 'Cycling of Matter in Lake Constance' (SFB 248 ). We strongly depended on the scientific cooperation realized within this project. We especially thank Alfred Sulger, captain of the RV 'Robert Lauterborn', and Thomas Gries, who took the initiative in the sediment trap program. Dieter Ollinger provided temperature data, Bärbel Beese measured chl a concentrations, Gisela Richter and Dietmar Straile contributed abundances of crustaceans, and Joachim Hentschel performed scanning electron microscopy. David J. S. Montagnes and an anonymous referee offered constructive criticism on the submitted manuscript.

\section{LITERATURE CITED}

Bloesch J, Burns NM (1980) A critical review of sedimentation trap technique. Schweiz Z Hydrol 42:15-55

Fauré-Fremiet E (1948) Le rythme de marée du Strombidium oculatum Gruber. Bull Biol Fr-Belg 82:3-23

Foissner W (1994) Progress in taxonomy of planktonic freshwater ciliates. Mar Microb Food Webs 8:9-35

Foissner W, Blatterer H, Berger H, Kohmann F (1991) Taxonomische und ökologische Revision der Ciliaten des Saprobiensystems. Band I.-Informationsberichte des Bayer Landesamtes für Wasserwirtschaft, München, 1/91

Gries T, Güde H (1999) Estimates of the non-consumptive mortality of mesozoo-plankton by measurements of sedimentation losses. Limnol Oceanogr 44:459-465

Jack DJ, Gilbert JJ (1997) Effects of metazoan predators on ciliates in freshwater plankton communities. J Eukaryot Microbiol 44:194-199

Jonsson PR (1994) Tidal rhythm of cyst formation in the rock pool ciliate Strombidium oculatum Gruber (Ciliophora, Oligotrichida): a description of the functional biology and an analysis of the tidal synchronization of encystment. J Exp Mar Biol Ecol 175:77-103

Kahl A (1932) Urtiere oder Protozoa. I: Wimpertiere oder Ciliata (Infusoria). 3. Spirotricha. Tierwelt Deutschlands 25 $299-650$

Editorial responsibility: Karel Simek

Ceské Budëjovice, Czech Republic
Kim YO, Taniguchi A (1995) Excystment of the oligotrich ciliate Strombidium conicum. Aquat Microb Ecol 9:149-156

Kim YO, Taniguchi A (1997) Seasonal variation of excystment pattern of the planktonic oligotrich ciliate Strombidium conicum. Mar Biol 128:207-212

Krainer KH. (1991) Contributions to the morphology, infraciliature and ecology of the planktonic ciliates Strombidium pelagicum n. sp., Pelagostrombidium mirabile (Penard, 1916) n.g., n. comb. and Pelagostrombidium fallax (Zacharias, 1896) n.g., n. comb., (Ciliophora, Oligotrichida). Eur J Protistol 27:60-70

Krainer KH (1995) Taxonomische Untersuchungen an neuen und wenig bekannten planktischen Ciliaten (Protozoa: Ciliophora) aus Baggerseen in Österreich. Lauterbornia 21:39-68

Müller $H$ (1989) The relative importance of different ciliate taxa in the pelagic food web of Lake Constance. Microb Ecol 18:261-273

Müller H (1996) Encystment of the freshwater ciliate Pelagostrombidium fallax (Ciliophora, Oligotrichida) in laboratory culture. Aquat Microb Ecol 11:289-295

Müller H, Geller W (1993) Maximum growth rates of aquatic ciliated protozoa: the dependence on body size and temperature reconsidered. Arch Hydrobiol 126:315-327

Müller H, Schöne A, Pinto-Coelho RM, Schweizer A, Weisse $T$ (1991) Seasonal succession of ciliates in Lake Constance. Microb Ecol 21:119-138

Paranjape MA (1980) Occurrence and significance of resting cysts in a hyaline tintinnid, Helicostomella subulata (Ehre.) Jorgensen. J Exp Mar Biol Ecol 48:23-33

Reid PC (1987) Mass encystment of a planktonic oligotrich ciliate. Mar Biol 95:221-230

Reid PC, John AW (1978) Tintinnid cysts. J Mar Biol Assoc UK 58:551-557

Reid PC, John AW (1983) Resting cysts in the ciliate class Polyhymenophorea: Phylogenetic implications. J Protozool 30:710-713

Sommer U (1984) Sedimentation of principal phytoplankton species in Lake Constance. J Plankton Res 6:1-14

Weisse T, Müller H (1998) Planktonic protozoa and the microbial food web in Lake Constance. In: Gaedke U, Bäuerle E (eds) Arch Hydrobiol Spec Issues: Advances in limnology: 'Lake Constance, characterization of an ecosystem in transition'. 53:223-254

Weisse $T$, Müller $H$, Pinto-Coelho $R$, Schweizer A, Springmann D, Baldringer G (1990) Response of the microbial loop to the phytoplankton spring bloom in a large prealpine lake. Limnol Oceanogr 35:781-794

Submitted: April 28, 1998; Accepted: July 22, 1998

Proofs received from author(s): March 26, 1999 